\title{
Traditional knowledge and uses of medicinal plants by the inhabitants of the islands of the São Francisco river, Brazil and preliminary analysis of Rhaphiodon echinus (Lamiaceae)
}

\author{
I. D. S. L. Pio ${ }^{a *}$, A. L. Lavor ${ }^{b}$, C. M. D. Damasceno ${ }^{a}$, P. M. N. Menezes ${ }^{\text {, F. S. Silva }}$ and \\ G. L. A. Maia ${ }^{a}$ \\ aPrograma de Pós-graduação em Ciências da Saúde e Biológicas, Universidade Federal do Vale do São Francisco - \\ UNIVASF, Av. José de Sá Maniçoba, s/n, Centro, CEP 56304-917, Petrolina, PE, Brasil \\ ${ }^{b}$ Colegiado de Ciências Farmacêuticas, Universidade Federal do Vale do São Francisco - UNIVASF, Av. José de Sá \\ Maniçoba, s/n, Centro, CEP 56304-917, Petrolina, PE, Brasil \\ 'Programa de Pós-graduação em Recurso Naturais do Semiárido, Universidade Federal do Vale do São Francisco - \\ UNIVASF, Av. José de Sá Maniçoba, s/n, Centro, CEP 56304-917, Petrolina, PE, Brasil \\ *e-mail: isabeldielle@gmail.com
}

Received: March 22, 2017 - Accepted: August 10, 2017 - Distributed: February 28, 2019

(With 2 figures)

\begin{abstract}
This study aimed to carry out an ethnobotanical survey of medicinal plants used by inhabitants of the Rodeadouro Island, Jatoba Island and Massangano Island, located in The Submedium São Francisco River Valley. Also phytochemicals and preliminary pharmacological tests were performed to species most cited by the community. Ethnobotanical data were collected through observation visits and semi-structured interviews with 12 key informants. We calculated the relative importance (RI), the percentage of agreement related to the main uses (cAMU) and use value (UV). The aerial parts of Rhaphiodon echinus (Ness \& Mart.) Schauer were used to obtain the lyophilizate (LYO-Re), crude ethanol extract (CEE-Re) and their hexanic (HEX-Re), chloroform (CLO-Re) and ethyl acetate (EA-Re) fractions. The microdilution technique was used for determining Minimum inhibitory concentration (MIC) for selected microorganisms. Already the spasmolytic effect was evaluated in isolated uterus fragments of Wistar rats, pre contracted with $\mathrm{KCl} 60 \mathrm{mM}$. We found 34 species cited, belonging to 22 families. The most plants were grown by locals. There were 51 different diseases, but the main indication was infectious and parasitic diseases. The species $R$. echinus was the most reported and it was indicated for urinary tract infection and dysmenorrhea. The screening revealed a higher prevalence of flavonoids, tannins, lignans and saponins in LYO-Re and AE-Re. Already terpene compounds were more present in HEX-Re and CLO-Re. The RE-Re fraction stood out with strong effect against E. coli and S. aureus while CEE-Re has moderate effect against gram-negative bacteria. The evaluation of the spasmolytic activity showed that LYO-Re, CEE-Re and HEX-Re fractions have similar activity, with partial effect and concentration-dependent response. This work brought about knowledge and use of medicinal plants by the riparian of the São Francisco River. It also revealed the importance of other methodologies for scientific evidence for the popular use of $R$. echinus.
\end{abstract}

Keywords: ethnobotany, traditional medicine, ethnopharmacology, traditional knowledge.

\section{Conhecimento tradicional e usos de plantas medicinais por habitantes das ilhas do rio São Francisco, Brasil e análise preliminar de Rhaphiodon echinus (Lamiaceae)}

\section{Resumo}

Objetivou-se realizar um levantamento etnobotânico de plantas medicinais utilizadas nas ilhas do Massangano, Jatobá II e Rodeadouro, localizadas entre Petrolina-PE e Juazeiro-BA, no submédio do rio São Francisco e posterior investigação fitoquímica e farmacológica da espécie mais citada, conforme a indicação da comunidade. Realizaram-se visitas de observação nas ilhas e os dados etnobotânicos foram coletados por entrevistas semiestruturadas com 12 informantes-chave. Calculou-se a Importância Relativa (IR), a Porcentagem Corrigida de Concordância quanto ao Uso Principal (CUPc) e o Valor de Uso (VU). Utilizaram-se as partes aéreas da espécie mais citada para obtenção do extrato etanólico bruto (EEB-Re), suas frações hexânica (HEX-Re), clorofórmica (CLO-Re) e acetato de etila (AE-Re); o produto liofilizado (LIO-Re) e o óleo essencial (OE-Re). A técnica de microdiluição foi usada para determinar a Concentração Inibitória Mínima (CIM) para microorganismos selecionados. A atividade espasmolítica foi avaliada em fragmentos isolados de útero de ratas Wistar pré-contraídos com KCl 60 mM. Foram relatadas 34 espécies, contidas em 22 famílias 
diferentes. A maioria das plantas era cultivada pelos moradores. Registraram-se 51 enfermidades diferentes, mas a principal indicação foi doenças parasitárias e infecciosas. A espécie Rhaphiodon echinus (Ness \& Mart.) Schauer foi a mais citada, com principal indicação para tratar infecção do trato urinário e dismenorreia. O screening fitoquímico revelou prevalência de flavonoides, taninos, lignanas e saponinas em LIO-Re e AE-Re e compostos terpênicos em HEX-Re e CLO-Re. Os testes antibacterianos mostraram que AE-Re é mais atuante contra E. coli e S. aureus do que para $P$. aeruginosa. O EEB-Re tem efeito parcial contra bactérias gram-negativas e OE-Re possui moderada resposta para todos microorganismos testados. LIO-Re, EEB-Re e HEX-Re possuem atividade espasmolítica dependente da concentração, sem diferença significativa e sem relaxamento total. Este trabalho trouxe conhecimento sobre o uso de plantas medicinais pelos ribeirinhos do rio São Francisco e revela a importância de estudos mais aprofundados para a comprovação científica do uso popular da $R$. echinus.

Palavras-chave: etnobotânica, medicina tradicional, etnofarmacologia, conhecimento tradicional.

\section{Introduction}

The search for reliefs and cures for diseases by using plants is possibly one of the first forms of human use of natural products (Zuanazzi and Mayorga, 2010). In Brazil, the use of herbs for medicinal purposes is a common practice, strengthened by the cultural diversity that came from colonization by European and African populations and indigenous traditional knowledge (Oliveira et al, 2011). Currently, estimates of the World Health Organization (WHO) stated that about $80 \%$ of the population uses the principles of traditional medicine in primary health care (Oliveira et al., 2010). This scenario, coupled with limitations of current pharmacotherapies, made pharmaceutical industries consider nature's resources as an important source of raw material for new drugs (Rates, 2001).

The Submedium São Francisco River Valley has an extension of about 700 kilometers. There are many fluvial islands located between the cities of Petrolina (Pernambuco) and Juazeiro (Bahia), in the northeastern region of Brazil. In these islands, the plants are subjected to the climate of the Caatinga, but have abundant water availability, constituting mixed vegetation (Godinho and Godinho, 2003). The association of the richness of plant species with poor access to health care caused the population of these islands to consolidate the use of resources of the region to treat and cure their ailments (Aquino, 2012). Considering the importance of the rescue of traditional knowledge of medicinal plants and of research of bioactive substances, this study aimed to carry out an ethnobotanical survey of medicinal plants used in communities of the Submedium São Francisco River Valley. Phytochemicals and preliminary pharmacological tests also were performed to species most cited by the community. This research is the first such work with the population of the islands. It contributes to enhance the knowledge of this community about the diversity of local vegetation.

\section{Material and Methods}

\subsection{Study area}

The study was conducted on three islands: Massangano Island, Jatoba Island and Rodeadouro Island, located in the Submedium São Francisco River Valley, between the cities of Petrolina, Pernambuco, and Juazeiro, Bahia. There are no official reports on the settlement process of these islands. Some records say that the island of Massangano began to be inhabited in 1830 and its name comes from a farmer who lived there and who owned much of the local land (Aquino, 2012). According to Article 20 of the Federal Constitution, paragraph IV, the river islands of São Francisco river are the property of the Union (Brasil, 1988), but most were inhabited by families who have no record of statutory individual ownership of the land. Thus only the houses are defined as individual plots, with the remainder of the territory regarded as an area for community use, regulated by custom and internally shared norms (Campos, 2002).

The soil is sandy and a range of less than $10 \mathrm{~m}$ wide at the edges of the islands is occupied by plants of riparian forests. Despite their importance for ecological and cultural reasons, these islands are not considered Permanent Preservation Areas (PPA) which represent fragile habitats under legal protection in the country (Brasil, 2012; Fabricante et al., 2015).

The visits were carried out during the months of December /2014 and January/2015. Twelve (12) key informants were selected, permanent residents, older than 18 years, with knowledge and skill with medicinal plants. In the sampling technique used, known as "snowball", a specialist recommends other with similar competence, repeating the process from new included (Andrade et al., 2006).

\subsection{Ethnobotanical data}

The ethnobotanical information of the use of plants was obtained through interviews based on semi-structured protocols with five triggering questions. The data on education, occupation and residence time on the islands were recorded to outline the profile of respondents. The people interviewed were asked to enumerate medicinal plants found locally and used frequently (popular name, preparation method and therapeutic indications). It was also asked about the reason for the use of medicinal plants and how this knowledge was obtained.

The plants cited were organized by common name, botanical family and species, statement, used parts and usage (Silva and Albuquerque, 2004). The species were identified by the comparison between individuals, studies on medicinal plants of the caatinga biome and the consultation of information sites of the The Plant List (2015) and 
The Missouri Botanical Garden (2016). The term status was used to refer to plant classification as spontaneous or cultivated in the answers to questions about how the informants could medicinal plants used. It was considered that wild species are those that occur naturally in the bush, without being cultivated, including in this category the native and invasive plants (Albuquerque et al., 2007).

The therapeutic indications were grouped based on the classification of diseases proposed by the World Health Organization (WHO, 2007) and the diseases or conditions that could not be included in this classification were grouped in category "general symptoms and signs".

In order to compare the species of medicinal plants to the importance of its use, it was calculated the relative importance (RI), based on the proposal of Bennett and Prance (2000) and according Albuquerque et al. (2007). The value of the RI has maximum 2.00 for a species. Plants with higher RI have more medicinal properties and act in various body systems (Albuquerque et al., 2006). Additionally, two other methodologies had used, named agreement on the main use (AMU) and use value (UV). For the UV calculation, it followed the methodology of Silva and Albuquerque, 2004. The comparison between the ethnobotanical indicators was made considering that each of the indexes evaluate different aspects of the relationship between man and plants. The RI and UV make reference to multiplicity of use of medicinal plants (Albuquerque et al., 2006). On the other hand cAMU evaluates how the therapeutic indication is consensus in the group of experts assessed (Amorozo and Gely, 1998).

\subsection{Preliminary phytochemical and pharmacological analysis of Rhaphiodon echinus (Nees \& Mart.) Schauer (Lamiaceae)}

The Rhaphiodon echinus samples collected $\left(09^{\circ} 27^{\prime} 36.10^{\prime \prime} \mathrm{S}, 040^{\circ} 34^{\prime} 46.50^{\prime \prime} \mathrm{W}\right)$ were prepared as exsiccate (I.D.S.L. Pio 1, $\mathrm{n}^{\circ} .22526$ ) and deposited in the "Vale do São Francisco Herbarium" (HVASF). The HVASF was responsible for making taxonomic classification.

Dried and powdered Rhaphiodon echinus samples were extracted with ethanol PA $95 \%$ by maceration $(3 \times 72 \mathrm{~h})$, yielding crude ethanol extract (CEE-Re) and after complete extraction the solvent was removed by distillation in rotary evaporator.. The crude ethanol extract was fractioned using hexane (HEX-Re), chloroform (CLO-Re) and ethyl acetate (EA-Re). Fractionates and the extract were stored in refrigerator for the following studies. The lyophilized (LYO-Re) was obtained by decoction following the orientations of the investigated community. The aqueous solution was filtered, lyophilized and stored in a dark bottle at $4{ }^{\circ} \mathrm{C}$. The lyophilized powder was reconstituted freshly before use.

\subsubsection{Phytochemical screening}

Preliminary identification of phytochemical of R. echinus was performed by screening by analytical thin layer chromatography using the method described by Wagner and Bladt (1996). It made even the differential search for alkaloids by using Mayer's reactive (iodine + potassium mercurato) as revealing.

\subsubsection{Pharmacological tests}

The determination of antimicrobial activity used the microorganisms: Pseudomonas aeruginosa ATCC 8027; Pseudomonas aeruginosa ATCC 23243; Staphylococcus aureus ATCC 25619; Staphylococcus aureus ATCC 25925; Escherichia coli 2536; Escherichia coli 105. The microorganisms were obtained from Tropical Culture Collection (CCT), American Type Culture Collection (ATCC) and clinical origin. The Minimal inhibitory concentration (MIC) determination was carried out by microdilution technique determined by Viljoen et al. (2003). A starting concentration of $100 \mathrm{mg} / \mathrm{ml}$ chloramphenicol (Merck) was used as a positive bacterial control and dimethylsulfoxide (DMSO) as negative control. MIC values were at least determined in duplicate.

The determination of spasmolytic activity was with virgin female Wistar rats (150-250 g) treated for 18 to 24 hours before the experiment with diethylstilbestrol (Merck) at a dose of $1.0 \mathrm{mg} / \mathrm{kg}$ subcutaneously to induce the estrus. The rats were euthanized by cervical dislocation and exsanguination. The uterus was removed, cleaned in a nutrient solution and each piece was individually suspended in glass tanks of a bath system for isolated

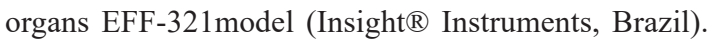
After stabilization, an initial isometric contraction was induced in each piece of the uterus using potassium chloride ( $\mathrm{KCl}$; Dynamic) $60 \mathrm{mM}$. Then the solutions of the extracts were added to the tanks individually and cumulatively in increasing concentrations $(1-729 \mu \mathrm{g} / \mathrm{ml})$ to obtain the results. Cremophor EL 3\% was used as negative control. Isometric contractions were recorded in computer through the WINDAQ / DATAQ DI200 software. The spasmolytic activity was assessed by relaxation, i.e. reversal of the contraction obtained by addition of $\mathrm{KCl}$. Numerical data were expressed as mean \pm standard error of the mean ( $x \pm$ s.e.m.). The sets of test data were statistically compared with the control group, by analysis of variance (ANOVA) and Tukey test. All statistical analyzes were performed using Prism 5 software for Windows (GraphPad Software Inc., San Diego, CA, USA), and the differences were considered significant when $p$-value $\leq 0.05$. The data were plotted in concentration-response curves adjusted by nonlinear regression. The results for each tested extract were expressed in $\mathrm{EC}_{50}$ value (concentration able to cause a 50\% maximal effect) and $\mathrm{E}_{\max }$ (maximal effect obtained in percentage).

This study was approved by the Research Ethics Committee and Ethics Committee on the Use of Animals of the Federal University of São Francisco Valley, with protocols $n^{\circ}$ 0006/240914 CEDEP / UNIVASF and 0006/120215 CEUA-UNIVASF, The free and informed consent was obtained by reading, full understanding and signature of the document of Informed Consent that contained adaptation to cultural and linguistic peculiarities of those involved. 


\section{Results and Discussion}

\subsection{Knowledge and use of medicinal plants}

The respondents had an average age of $64.83 \pm 16.95$ years with a female majority (83\%). Most had little or no schooling, and lived on the islands for many years (median years 44.58 years). These communities have a diverse ethnic composition including indigenous descendants, sons of miners, boatmen and farmers and cowboys of the northeastern Brazilian region. However, these people retain their identity, based on "being of the island" that is strengthened every day with in cultural rituals and commemorations (Aquino, 2012).

The use of plants in health care is a daily activity on the islands. This knowledge was transmitted orally from generation to generation. The oral transmission of traditional knowledge is well elucidated in other ethnodirected studies (Carneiro et al., 2010; Firmo et al., 2012; Griz et al., 2017) (Table 1).

The determinants for the use of medicinal plants were defined as confidence in the potential of natural resources; preference front industrialized pharmaceuticals and ease of access. These reasons have been identified in several studies (Alvim et al., 2006; Carreira and Alvim, 2008; Rodrigues and Carvalho, 2001; Stalcup, 2000). However it is possible that plants are widely used also because of their lower prices when compared to synthetic drugs or because plants present a more viable alternative to the difficulties of access to medical care (Stalcup, 2000).

The Table 1 also shows that the most common forms of use were tea, bath and syrup. These forms of preparation were well reported in other studies of the Brazilian Northeast (Moreira et al., 2002; Freitas et al., 2012). Few listed plants were found simultaneously in the region and this was explained by the environmental changes (for example, small animal breeding that led to reduction of the original vegetation) forcing the residents to cultivate plants in peridomestic regions. This confirms the proposition Amorozo (2002) which says that the anthropic actions arising from changes in patterns of use of local natural resources can reduce the availability of plants with status of native and spontaneous.

Table 1. Data on knowledge and use of medicinal plants of residents $(n=12)$ of Massangano Island, Rodeadouro Island and Jatoba Island (PE/BA), 2015.

\begin{tabular}{|c|c|c|c|c|}
\hline Inf* & $\begin{array}{c}\text { Source of } \\
\text { knowledge about } \\
\text { medicinal plants }\end{array}$ & Reason for use of medicinal plants & $\begin{array}{c}\text { Main forms of } \\
\text { use of medicinal } \\
\text { plants }\end{array}$ & $\begin{array}{l}\text { Status of the most } \\
\text { used medicinal plants }\end{array}$ \\
\hline 01 & $\begin{array}{l}\text { Family of } \\
\text { indigenous } \\
\text { descents } * *\end{array}$ & $\begin{array}{l}\text { Belief and because they easily found on the } \\
\text { island. }\end{array}$ & $\begin{array}{l}\text { Teas; baths; } \\
\text { infusion }\end{array}$ & Cultivates at home \\
\hline 02 & Parents & $\begin{array}{l}\text { Feels better than when using industrialized } \\
\text { drugs }\end{array}$ & Teas; baths & Cultivates at home \\
\hline 03 & Mother & Preference for natural products & $\begin{array}{l}\text { Teas; syrup; } \\
\text { juices }\end{array}$ & $\begin{array}{l}\text { Cultivates at home and } \\
\text { neighborhood }\end{array}$ \\
\hline 04 & $\begin{array}{l}\text { Older family } \\
\text { members }\end{array}$ & Preference for natural products & Teas; syrup* & $\begin{array}{l}\text { Cultivates at home and } \\
\text { spontaneus }\end{array}$ \\
\hline 05 & Grandmother & Preference for natural products & $\begin{array}{l}\text { Teas; syrup; } \\
\text { baths }\end{array}$ & $\begin{array}{l}\text { Cultivates at home and } \\
\text { spontaneus }\end{array}$ \\
\hline 06 & Parents & Confidence in the potential of plants & Teas; baths & $\begin{array}{l}\text { Cultivates at home and } \\
\text { spontaneus }\end{array}$ \\
\hline 07 & Family & $\begin{array}{c}\text { Feels better than when using industrialized } \\
\text { drugs }\end{array}$ & Teas; baths & Cultivates at home \\
\hline 08 & Mother & $\begin{array}{c}\text { Believes more in plants than in } \\
\text { industrialized drugs }\end{array}$ & $\begin{array}{l}\text { Teas; juices; } \\
\text { "in natura } \\
\text { consumption" }\end{array}$ & $\begin{array}{l}\text { Cultivates at home and } \\
\text { spontaneus }\end{array}$ \\
\hline 09 & Family & Confidence in the potential of plants & Teas & $\begin{array}{l}\text { Cultivates at } \\
\text { neighborhood and } \\
\text { spontaneus }\end{array}$ \\
\hline 10 & Parents & $\begin{array}{l}\text { Why live in places with abundant } \\
\text { medicinal plants ; ease of access }\end{array}$ & Teas; baths & Cultivates at home \\
\hline 11 & Mother & $\begin{array}{c}\text { Feels better than when using industrialized } \\
\text { drugs }\end{array}$ & Teas; syrup & $\begin{array}{l}\text { Cultivates at home and } \\
\text { spontaneus }\end{array}$ \\
\hline 12 & $\begin{array}{l}\text { Older family } \\
\text { members }\end{array}$ & Best alternative care & Teas; baths & Cultivates at home \\
\hline
\end{tabular}

*Informant's identification number; **Several family members were quoted as uncles, grandparents and great-grandparents. Source: Authors. 
Although there are no specific studies on the subject, it is clear that the status of medicinal plants used in traditional communities is a topic that has been discussed by ethnobotany researchers (Albuquerque and Andrade, 2002a; Amorozo, 2002; Batista Silva et al., 2015; Carneiro et al., 2010). It is possible that the status change of used medicinal plants is a reflection of the characteristics of each community, or of their care practices, the relationship with nature, or of the exchange of information between ethnically distinct peoples.

In the medicinal plants free-listing, the respondents identified 34 different species, belonging to 22 families and 51 different indications (Table 2). The most common family was Lamiaceae who were also often cited in studies of Moreira et al. (2002) and Souza et al. (2002). In addition, Lamiaceae and Asteraceae were often cited in the collection of medicinal plants of the caatinga, made by Albuquerque et al. (2007). They are also among the most representative in ethnobotanical study conducted in other Brazilian biome, the Atlantic Forest (Gazzaneo et al., 2005).

The leaves were further part of the plant used, with $73.5 \%$ of citations. However found other studies of the caatinga with different results (Albuquerque and Andrade, 2002a, b; Almeida et al., 2006). Albuquerque and Andrade (2002b) emphasize that in the caatinga biome, usually the stem or its bark is collected for medicinal use due to continuous supply of these resources (since they are minimally affected by water irregularity). So it appears that seasonality significantly influences the relationship between people and plants in the region (Table 2).

The highest number of reported medicinal species had indications in infectious and parasitic diseases, such as intestinal infections, diarrhea and worms (17.14\%), followed by the genito-urinary problems $(14.28 \%)$ and skin problems and subcutaneous fabric (11.43\%) (Figure 1). A great reference these medical problems is justified by its high prevalence in the region, but also because they belong to the scope of primary health care. Thus, these diseases can be easily and effectively treated with medicinal plants (Almeida et al., 2006). Unlike what was seen, others studies of the caatinga biome more reference indications related to the respiratory system (Albuquerque and Andrade, 2002a, b; Freitas et al., 2012; Roque et al, 2010). It is important to emphasize the subjectivity that characterizes the identification of these medical problems, changing from community to community. This difference confirms the idea that each social group has its own diagnostic system, classification (Moreira et al., 2002) and treatment of diseases, influenced by their beliefs and worldviews.

Table 2. Plant resources used by residents $(n=12)$ of Massangano Island, Rodeadouro Island and Jatoba Island (PE/BA), 2015.

\begin{tabular}{|c|c|c|c|c|c|c|}
\hline $\mathbf{N}$ & $\begin{array}{l}\text { COMMON } \\
\text { NAME }\end{array}$ & SPECIES & INDICATION & $\begin{array}{l}\text { PART } \\
\text { USED }\end{array}$ & $\begin{array}{c}\text { METHOD OF } \\
\text { USE }\end{array}$ & RI \\
\hline \multicolumn{7}{|c|}{ 1. Lamiaceae Family* } \\
\hline 01 & Agua-de-alevante & Mentha gentilis L. & Hypertension & Leaves & Infusion & 0.8 \\
\hline 02 & Erva-cidreira & Melissa officinalis L. & Intestinal colic & Leaves & Tea & 0.8 \\
\hline 03 & $\begin{array}{l}\text { Hortelã, } \\
\text { Hortelã-miúda }\end{array}$ & $\begin{array}{c}\text { Mentha } x \text { villosa } \\
\text { Huds. }\end{array}$ & $\begin{array}{l}\text { Flu; intestinal } \\
\text { colic }\end{array}$ & Leaves & Tea & 2.0 \\
\hline 04 & Betônica & $\begin{array}{l}\text { Rhaphiodon echinus } \\
\text { (Nees \& Mart.) } \\
\text { Schauer }\end{array}$ & $\begin{array}{l}\text { Flu; intestinal } \\
\text { colic }\end{array}$ & Leaves & Tea, bath & 2.0 \\
\hline 05 & $\begin{array}{l}\text { Vick, Hortelã- } \\
\text { Vick, }\end{array}$ & Mentha arvensis L. & Flu & Leaves & Tea & 0.8 \\
\hline \multicolumn{7}{|c|}{ 2. Anacardiaceae Family } \\
\hline 06 & Aroeira & $\begin{array}{c}\text { Myracrodruon } \\
\text { urundeuva Allemao }\end{array}$ & $\begin{array}{c}\text { Urinary tract } \\
\text { infection and } \\
\text { dermatological }\end{array}$ & Stalk & Infusion & 1.7 \\
\hline 07 & Cajueiro & $\begin{array}{c}\text { Anacardium } \\
\text { occidentale L. }\end{array}$ & $\begin{array}{l}\text { Diabetes mellitus; } \\
\text { healing }\end{array}$ & Stalk & Infusion & 17 \\
\hline 08 & Mangueira & Mangifera indica L. & $\begin{array}{l}\text { Whooping cough; } \\
\text { respiratory } \\
\text { infection }\end{array}$ & Leaves & Tea & 0.8 \\
\hline \multicolumn{7}{|c|}{ 3. Fabaceae Family } \\
\hline 09 & Jatobá & $\begin{array}{c}\text { Hymenaea courbaril } \\
\text { L. }\end{array}$ & Anemia & Stalk & Infusion & 0.8 \\
\hline 10 & Pau-ferro & $\begin{array}{c}\text { Caesalpinia férrea } \\
\text { Mart. }\end{array}$ & Anemia & Stalk & Molasses & 0.8 \\
\hline 11 & Jurema-preta & $\begin{array}{l}\text { Mimosa tenuiflora } \\
\text { (Willd) Poir. }\end{array}$ & Skin lesions & Stalk & Bath & 0.8 \\
\hline
\end{tabular}

*Classification based on site information The Plant List (2015). Source: Authors. 
Table 2. Continued...

\begin{tabular}{|c|c|c|c|c|c|c|}
\hline $\mathbf{N}$ & $\begin{array}{c}\text { COMMON } \\
\text { NAME }\end{array}$ & SPECIES & INDICATION & $\begin{array}{l}\text { PART } \\
\text { USED }\end{array}$ & $\begin{array}{c}\text { METHOD OF } \\
\text { USE }\end{array}$ & RI \\
\hline \multicolumn{7}{|c|}{ 4. Malvaceae Family } \\
\hline 12 & $\begin{array}{l}\text { Malva-santa, } \\
\text { Malva-branca }\end{array}$ & Sida cordifolia $\mathrm{L}$ & $\begin{array}{c}\text { inflammatory } \\
\text { processes; } \\
\text { healing; diarrhea }\end{array}$ & Leaves & Tea & 2.0 \\
\hline 13 & Quiabo & $\begin{array}{l}\text { Abelmoschus } \\
\text { esculentus (L.) } \\
\text { Moench }\end{array}$ & $\begin{array}{c}\text { inflammatory } \\
\text { processes; } \\
\text { healing; diarrhea }\end{array}$ & Leaves & Tea & 0.8 \\
\hline 14 & Colônia & $\begin{array}{l}\text { Alpinia speciosa } \\
\text { (Blume) D. Dietr. }\end{array}$ & Hypertension & Leaves & Tea & 0.8 \\
\hline 15 & Gengibre & $\begin{array}{c}\text { Zingiber officinale } \\
\text { Roscoe }\end{array}$ & Joint pain, flu & Roots & Tea, syrup & 0.8 \\
\hline \multicolumn{7}{|c|}{ 6. Asteraceae Family } \\
\hline 16 & Macela & $\begin{array}{c}\text { Egletes viscosa (L.) } \\
\text { Less. }\end{array}$ & Intestinal colic & Leaves & Tea & 0.8 \\
\hline 17 & Picão-preto & Bidens sp. & $\begin{array}{l}\text { Whooping cough; } \\
\text { respiratory } \\
\text { infection }\end{array}$ & Leaves & Tea & 1.7 \\
\hline \multicolumn{7}{|c|}{ 7. Rutaceae Family } \\
\hline 18 & Arruda & Ruta graveolens L. & $\begin{array}{c}\text { Urinary tract } \\
\text { infection; colic, } \\
\text { digestive }\end{array}$ & Leaves & Tea, juice & 1.5 \\
\hline 19 & Limão & $\begin{array}{c}\text { Citrus limonum } \\
\text { Russo }\end{array}$ & Worm & Fruit & Juice & 0.8 \\
\hline \multicolumn{7}{|c|}{ 8. Xanthorrhoeaceae Family } \\
\hline 20 & Babosa & $\begin{array}{c}\text { Aloe vera (L.) Burm. } \\
\text { f. }\end{array}$ & Worm & Leaves & Juice & 0.8 \\
\hline \multicolumn{7}{|c|}{ 9. Amaryllidaceae Family } \\
\hline 21 & Cebola & Allium cepa $\mathrm{L}$. & Diabetes mellitus & Leaves & Tea & 0.8 \\
\hline \multicolumn{7}{|c|}{ 10. Aristolochiaceae Family } \\
\hline 22 & Jarrinha & Aristolochia sp. & Flu & Roots & Syrup & 0.8 \\
\hline \multicolumn{7}{|c|}{ 11. Myristicaceae Family } \\
\hline 23 & Noz moscada & $\begin{array}{c}\text { Myristica fragrans } \\
\text { Houtt. }\end{array}$ & Articular pain & Seed & Tea & 0.8 \\
\hline \multicolumn{7}{|c|}{ 12. Rhamnaceae Family } \\
\hline 24 & Juazeiro, Juá & $\begin{array}{l}\text { Ziziphus joazeiro } \\
\text { Mart. }\end{array}$ & Flu, tooth decay & Stalk & Powder (topic) & 1.7 \\
\hline \multicolumn{7}{|c|}{ 13. Lauraceae Family } \\
\hline 25 & $\begin{array}{c}\text { Abacate, } \\
\text { Abacateiro }\end{array}$ & $\begin{array}{c}\text { Persea americana } \\
\text { Mill. }\end{array}$ & Renal pain & Leaves & Tea & 0.8 \\
\hline \multicolumn{7}{|c|}{ 14. Moraceae Family } \\
\hline 26 & $\begin{array}{c}\text { Amoreira } \\
\text { Amora-negra }\end{array}$ & Morus nigra L. & Weight Loss & Leaves & Tea & 0.8 \\
\hline 27 & Capim-santo & $\begin{array}{c}\text { Cymbopogon } \\
\text { citrates (DC.) Stapf }\end{array}$ & Hypertension & Leaves & Tea & 0.8 \\
\hline \multicolumn{7}{|c|}{ 16. Combretaceae Family } \\
\hline 28 & Castanhola & Terminalia catappa $\mathrm{L}$. & Renal pain & Leaves & Tea & 0.8 \\
\hline \multicolumn{7}{|c|}{ 17. Annonaceae Family } \\
\hline 29 & Graviola & Annona muricata L. & Renal pain & Leaves & Tea & 0.8 \\
\hline
\end{tabular}


Table 2. Continued...

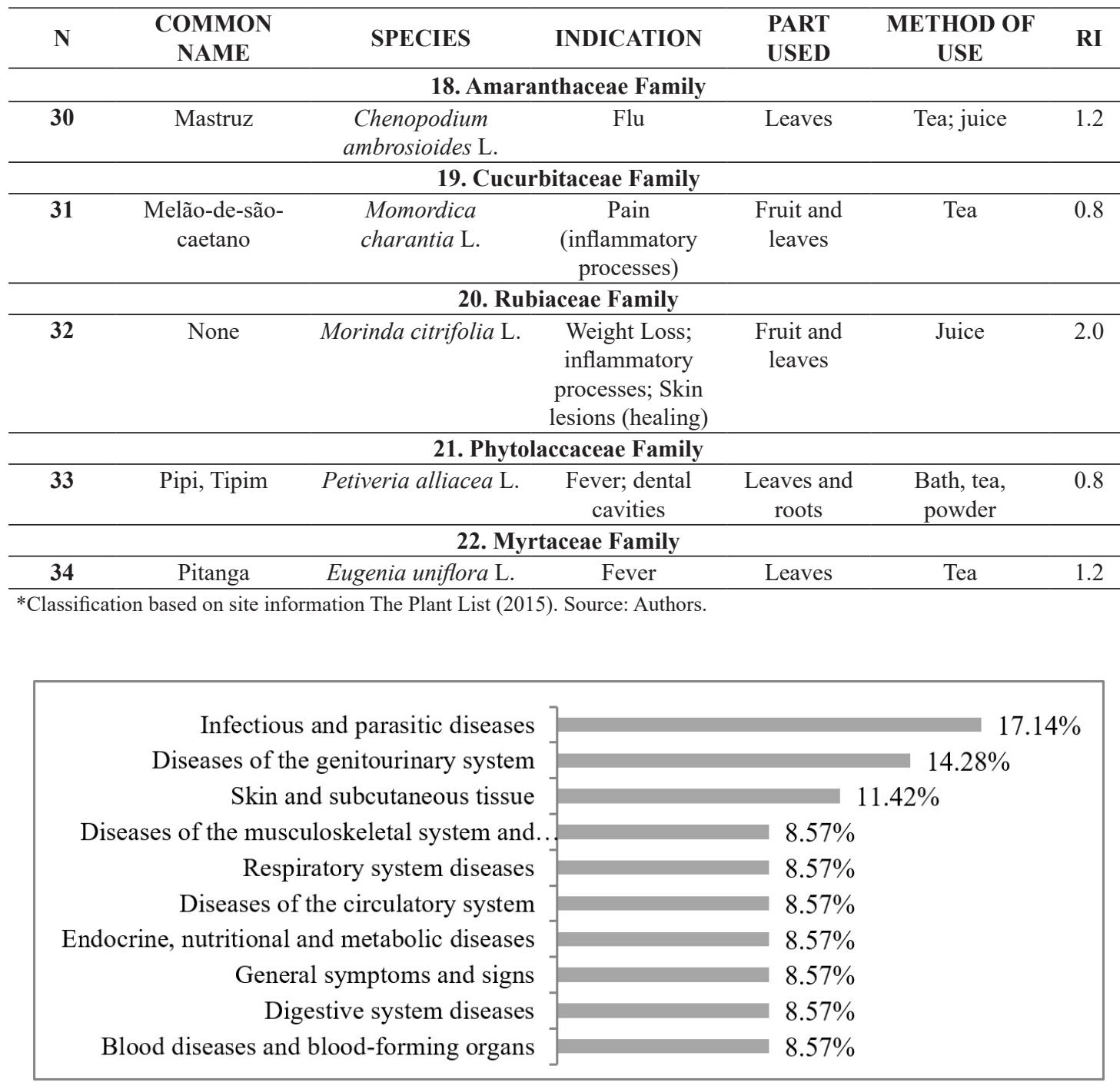

Figure 1. Percentage of medicinal plants cited by residents of Massangano Island, Rodeadouro Island and Jatoba Island (PE/BA), distributed by chapters of ICD 10, 2015. Source: Authors.

\subsection{More important medicinal plants}

According to the RI shown in Table 2, the most important plants for this community were: Rhaphiodon echinus, Malva parviflora, Morinda citrifolia, Menthax villosa $(\mathrm{RI}=2.0)$, Myracrodruon urundeuva, Anacardium occidentale, Ziziphus joazeiro e Bidens sp. (RI=1.7). Some studies in areas of caatinga (Albuquerque and Andrade, 2002a, b; Albuquerque et al., 2007; Freitas et al., 2012) also indicate the use of these species in folk medicine, except for Morinda citrifolia. However, RI values for the most important plants in this study are very different from the amounts presented in an analytical study of 21 scientific publications (1986-2006), directed by Albuquerque et al. (2007). As an example, there is the set of IR values Raphiodon echinus and Sida cordifolia $(\mathrm{IR}=2.0$ ) very discrepant from those found in Albuquerque et al. (2007) (IR $=0.2$ and 0.5 , respectively). This significant difference stems from the different individual perceptions of natural resources in a given environment. The meaning of utility for medicinal plants changes between cultures and even among people of the same community. This concept becomes even greater when extrapolated understanding the utility beyond medicinal purposes (Albuquerque and Andrade, 2002b).

There was no information to Morinda citrifolia, possibly because this Polynesian origin plant only reached the US market in the 1990s (Potterat and Hamburger, 2007) and in Brazil only in the 2000s. Therefore the national scientific research for this species yet it is quite recent. 
Thus the joint analysis of these three ethnobotanical indicators (RI, cAMU and UV) shows that the importance of a medicinal plant for a community is defined by its versatility and the consistency of information obtained by respondents. The comparison of indicators revealed Rhaphiodon echinus (called popularly "Betônica" or "Flor-de-urubu") as the most important medicinal plant to the community studied (Table 3 ). This means that this plant has importance in health care that people, both the versatility of therapeutic indications described in IR and VU, but also by the degree of consensus on its main use, among the experts interviewed (defined by cAMU). That is why preliminary tests were conducted to identify the phytochemical composition and pharmacological activity of extracts of $R$. echinus.

\subsection{Chemical constituents of Rhaphiodon echinus}

The Betônica (Rhaphiodon echinus) belongs to Lamiaceae family, subfamily Ocimoideae, subtribe Hyptidineae (Forzza et al., 2010). It is a creeping plant and its main characteristics are the presence of fruitful cup with spinescent lacínios and prostrate habit. $R$. echinus is considered invasive, typical of the caatinga biome, with wide distribution in Brazil, located in the states of Bahia, Pernambuco, Paraíba, Ceará and Minas Gerais (Dias and Kiill, 2007). This plant commonly occurs in areas of irrigated fruit in the São Francisco Valley, where it forms dense populations.

In the interviews, the residents said the main indication of $R$. echinus is urinary tract infections and dysmenorrhea. This information also appears in the study of Albuquerque et al. (2007). Another study reports that $R$. echinus is used to treat cough and dental inflammation (Menezes et al., 1998). The aqueous extract of this plant has anti-inflammatory and analgesic activity (Torres et al., 2009) and its essential oil has antimicrobial effect against E. coli and K. pneumoniae (Souza and Rodrigues, 2012).

In the screening phytochemical HEX-Re, CLO-Re and AE-Re fractions and the LYO-Re showed a higher prevalence of flavonoids and tannins, lignans and saponin. It is described in the scientific literature that flavonoids, saponins and terpenes are constituents found in many Lamiaceae family species as Orthosiphon Stamineus Benth, Mentha spicata L., Coleus amboinicus Lour, Ocimum basilicum L., Bolivian Satureja (Benth) Briq. L. and Ocimum gratissimum. The concentration of these compounds may vary depending on the solvent of each phase. But these metabolites are always present and can be a mark of this family (Andrade et al., 2010; Fiuza et al., 2010; Galvez et al., 1993).

All fractions showed the presence of flavonoids. Those compounds are important because of its various activities on the biological system, in particular, on the cardiovascular system and antioxidant action (Andrade et al., 2010; Scur et al., 2016). In the digestive system, some flavonoids have been reported with antispasmodic potential (Galvez et al., 1993). Moreover the species Hyptis - most studied genus of subtribe Hyptidineae - are recognized for having medicinal properties with antioxidant potential, attributing part of its therapeutic properties to phenolic compounds detected (Povh et al., 2012).

The HEX-Re and CLO-Re showed the mainly presence of terpenes and steroids components.

This result is supported by the study Menezes and Kaplan (2006) have identified a mixture of pentacyclic triterpenes in crude acetone extract of $R$. echinus. In addition, some work on the Hyptis gender report high concentration of terpene compounds, considered the main components of

Table 3. Comparison ethnobotanical indicators for the plants most often cited by residents of Massangano Island, Rodeadouro Island and Jatoba Island (PE/BA), 2015.

\begin{tabular}{|c|c|c|c|c|}
\hline COMMOM NAME & $\begin{array}{l}\text { FAMILY } \\
\text { SPECIES }\end{array}$ & RI* & $\mathbf{V U} * *$ & $\begin{array}{l}\text { CAMU } \\
(\%) * * *\end{array}$ \\
\hline Betônica & $\begin{array}{c}\text { Lamiaceae } \\
\text { Rhaphiodon echinus (Nees \& Mart.) Schauer }\end{array}$ & 2.0 & 1.7 & 83.3 \\
\hline Malva-santa & $\begin{array}{l}\text { Malvaceae } \\
\text { Sida cordifolia } \mathrm{L} \text {. }\end{array}$ & 2.0 & 1.0 & 16.7 \\
\hline None & $\begin{array}{c}\text { Rubiaceae } \\
\text { Morinda citrifolia } \mathrm{L}\end{array}$ & 2.0 & 1.5 & 16.7 \\
\hline Hortelã & $\begin{array}{c}\text { Lamiaceae } \\
\text { Mentha } x \text { villosa Huds. }\end{array}$ & 2.0 & 2.0 & 33.3 \\
\hline Cajueiro & $\begin{array}{c}\text { Anacardiaceae } \\
\text { Anacardium occidentale } L\end{array}$ & 1.7 & 1.0 & 33.3 \\
\hline Aroeira & $\begin{array}{c}\text { Anacardiaceae } \\
\text { Myracrodruon urundeuva Allemao }\end{array}$ & 1.7 & 1.3 & 50.0 \\
\hline Juazeiro & $\begin{array}{c}\text { Rhamnaceae } \\
\text { Ziziphus joazeiro Mart. }\end{array}$ & 1.7 & 1.0 & 16.7 \\
\hline Picão-preto & $\begin{array}{l}\text { Asteraceae } \\
\text { Bidens } \mathrm{sp} \text {. }\end{array}$ & 1.7 & 2.0 & 16.7 \\
\hline
\end{tabular}

*RI: Relative Importance; **UV: Use Value; ***AMU: Agreement on the Main Use. Source: Authors. 
the essential oils of these species (Basílio et al., 2007; Falcão et al., 2003; Moreno et al, 2005; Torres et al, 2009). Terpenes have great importance in the new drugs research area, since they have different biological activities, such as expectorant, anesthetic, carminative, anthelmintic, antispasmodic and antiseptic (Astudillo-Vázquez et al., 2009). The therapeutic potential of terpenes can explain the popular use of $R$. echinus observed.

The alkaloids detection tests suggested the presence of these metabolites in the composition R. echinus. We did not find other studies confirming this result. However, the scientific literature suggests the existence of different metabolism in some Lamiaceae representatives, as the Hyptis genus characterized by remarkable variability. A study of Falcão et al. (2003) reported the isolation of a compound alkaloid, (R) -5-hydroxypyrrolidine-2-one, from Hyptis verticillata extract.

\subsubsection{Antimicrobial activity of R. echinus}

Because of the increasing development of drug resistance to human pathogens, medicinal plants have been extensively studied as alternative agents for the prevention and treatment of infections (Höfling et al., 2010). According to the classification by Sartoratto et al. (2004), Re -EA showed strong antimicrobial potential against $E$. coli and $S$. aureus and a moderate effect on $P$. aeruginosa. Furthermore the CEE-Re showed moderate effect against gram-negative bacteria (Table 4).

The results of phytochemical screening indicate that EA-Re and LYO-Re fractions contain high concentration of phenolic compounds. The antimicrobial activity of $\mathrm{AE}$ -Re might be attributed to the presence of the foresaid secondary metabolites. However the LYO-Re fraction did not show antimicrobial activity, which can be explained by the variation of the concentration of metabolites in each fraction (Andreo and Jorge, 2006).

\subsubsection{Spasmolytic activity R. echinus}

The spasmolytic substances have wide application in pathophysiological processes, such as hypertension, cardiac arrhythmias, angina pectoris, diarrhea, intestinal spasms, asthma and menstrual colic (Souza et al., 2013). Then the use of these substances in the uterine muscle may represent an important therapeutic alternative in combating problems like dysmenorrhea or diseases in pregnancy (Young, 2007). Therefore the research conducted in this study revealed that CEE-Re, LYO-Re e HEX-Re relaxed utero fragment rats, pre-contracted with $\mathrm{KCl} 60 \mathrm{mM}$ with concentration-dependent response.

The three derivatives $R$. echinus showed similar activity without statistical difference (Figure 2). None of them could completely relax the uterine muscle, although the HEX-Re has reached about $80 \%$ of the relaxation (Figure 2A). There was no statistically difference in the mean values of $\mathrm{EC}_{50}$ (the extracts were equipotents) (Figure 2B). As for the $\mathrm{E}_{\max }$ (relative efficacy parameter) the HEX-Re fraction was more effective compared to other two products tested (Figure 2C).

No records were found in the literature on the spasmolytic properties of the species R. echinus. For the Lamiaceae family, there were few studies which showed activity of the same species on uterine muscle, but with spasmogenic or uterotonic activity, that is, with opposing goals for this study (Ladeji et al., 2005; Chen et al., 2000; Gruber and O'Brien, 2011; Kamatenesi-Mugisha and Oryem-Origa, 2007). However, other studies have indicated the spasmolytic property of essential oils of plants, such as the study Centeno (2010), for the essential oil of Rosmarinus officinalis L. and Shih et al. (2009) which assessed one flavonoid from Scutellaria baicalensis Georgi in reducing contractions in the uterus of female rats.

The absence of previous studies with $R$. echinus should be considered a limitation to this study, given the

Table 4. Antimicrobial activity of extracts and fractions of the aerial parts of R. echinus, Petrolina (PE), 2015.

\begin{tabular}{|c|c|c|c|c|c|c|}
\hline \multirow{3}{*}{ SAMPLE } & \multicolumn{6}{|c|}{ BACTERIAL STRAINS } \\
\hline & $\begin{array}{c}\text { S. aureus } \\
\text { ATCC } 25619\end{array}$ & $\begin{array}{c}\text { S. aureus } \\
\text { ATCC } 25925\end{array}$ & $\begin{array}{c}\text { P. aeruginosa } \\
\text { ATCC } \\
8027\end{array}$ & $\begin{array}{c}\text { P. aeruginosa } \\
\text { ATCC } \\
25243\end{array}$ & $\begin{array}{c}\text { E. coli } \\
\text { ATCC } \\
2536\end{array}$ & $\begin{array}{c}\text { E. coli } \\
\text { ATCC } \\
105\end{array}$ \\
\hline & $\begin{array}{c}\mathrm{MIC} \\
(\mathrm{mg} / \mathrm{mL})\end{array}$ & $\begin{array}{c}\text { MIC } \\
(\mathrm{mg} / \mathrm{mL})\end{array}$ & $\begin{array}{c}\text { MIC } \\
(\mathrm{mg} / \mathrm{mL})\end{array}$ & $\begin{array}{c}\text { MIC } \\
(\mathrm{mg} / \mathrm{mL}) \\
\end{array}$ & $\begin{array}{c}\text { MIC } \\
(\mathrm{mg} / \mathrm{mL})\end{array}$ & $\begin{array}{c}\text { MIC } \\
(\mathrm{mg} / \mathrm{mL})\end{array}$ \\
\hline LYO-Re & - & - & - & - & - & - \\
\hline CEE-Re & - & - & 1.024 & 1.024 & 1.024 & 1.024 \\
\hline HEX-Re & - & - & - & - & - & - \\
\hline CLO-Re & - & - & - & - & - & - \\
\hline AE-Re & 0.512 & 1.024 & 1.024 & 1.024 & 0.512 & 0.512 \\
\hline Neg. Con.* & - & - & - & - & - & - \\
\hline Pos. Con.** & + & + & + & + & + & + \\
\hline
\end{tabular}

LYO-Re: lyophilized (aqueous extract); CEE-Re: crude ethanol extract; HEX-Re: hexane fraction; CLO-Re: chloroform fraction; AE-Re: Ethyl Acetate Fraction; *Negative control: DMSO; **Positivo control: chloramphenicol, $100 \mu \mathrm{g} / \mathrm{mL}$. Note: Antimicrobial potential classification (Sartoratto et al., 2004): (1) Strong antimicrobial power $=0.05 \leq \mathrm{MIC} \leq 0.5 \mathrm{mg} / \mathrm{mL}$; (2) moderate antimicrobial power $=0.6 \leq \mathrm{MIC} \leq 1.5 \mathrm{mg} / \mathrm{mL}$ e; (3) weak antimicrobial power $=\mathrm{MIC} \geq 1.6 \mathrm{mg} / \mathrm{mL}$. Source: Authors. 

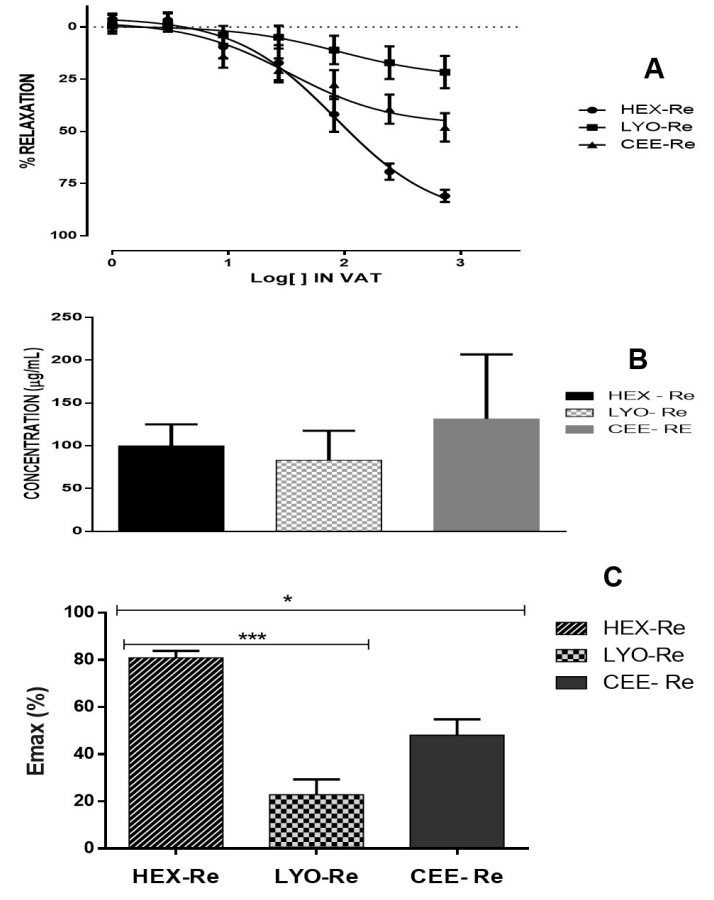

Figure 2. Effect of spasmolytic derived from $R$. echinus on the tonic contractions induced with $60 \mathrm{mM} \mathrm{KCl}$ in rat isolated uterus Petrolina (PE), 2015. (A) concentration-response curves; (B) $\mathrm{EC}_{50}$ values of the tested compounds; (C) $\mathrm{E}_{\max }$ values for the tested compounds. Data are presented as mean \pm S.E.M. $(\mathrm{N}=5)$. ${ }^{*}$ Represents Emax values were statistically different (ANOVA, p < 0.05); ***Represents Emax values were statistically different (ANOVA, $\mathrm{p}<0.01$ ). LYO-Re: lyophilized (aqueous extract); CEE-Re: crude ethanol extract; HEX-Re: hexane fraction. Source: Authors.

difficulty of drawing comparisons. However it reinforces the relevance of this research to the knowledge of the Lamiaceae family and the plant considered so important by the riparian river São Francisco.

\section{Conclusions}

In this study was reported the use of 34 different medicinal plants. The most common form of use was tea and the reason for the use of medicinal plants was the confidence in the potential of natural resources. The main indications for the use of medicinal plants were different conditions from those carried out in other studies conducted in the caatinga biome. This difference can have a relationship with local care systems, specific to each community.

The comparison of ethnobotanical indicators revealed the importance of $R$. echinus between the riparians of São Francisco River, justifying the phytochemical and pharmacological research conducted then.

The ethnopharmacological data were results of unpublished reports of evaluation of action in two experimental models in vitro. However the weak antimicrobial activity and spasmolytic of the LYO-Re (preparation similar to the form of use reported by experts) inserts doubts about the popular indication for use of $R$. echinus. Therefore, the scientific evidence for the traditional use of this medicinal plant requires further confirmations based on other experimental protocols.

This study provides an advance to approximate the popular knowledge with the research developed within the University. Thus, the prospect of this work is to collaborate with academic and scientific activities committed to valorization of the identity of the residents of the islands of the São Francisco river, while contributing to the investigation of natural resources with therapeutic potential from the regional flora.

\section{Acknowledgements}

The "people of the island", residents of Massangano, Jatoba and Rodeadouro Islands, for their reception and care in research collaboration.

\section{References}

ALBUQUERQUE, U.P. and ANDRADE, L.H.C., 2002a. Uso de recursos vegetais da caatinga: o caso do agreste do estado de Pernambuco (Nordeste do Brasil). Interciencia, vol. 27, pp. 336-346.

ALBUQUERQUE, U.P. and ANDRADE, L.H.C., 2002 b. Conhecimento botânico tradicional e conservação em uma área de caatinga no Estado de Pernambuco, Nordeste do Brasil. Acta Botanica Brasílica, vol. 16, no. 3, pp. 273-285. http://dx.doi. org/10.1590/S0102-33062002000300004.

ALBUQUERQUE, U.P., LUCENA, R.F.P., MONTEIRO, J.M., FLORENTINO, A.T.N. and ALMEIDA, C.F.C.B.R., 2006. Evaluating two quantitative ethnobotanical techniques. Ethnobotany Research and Applications, vol. 4, pp. 51-60. http:// dx.doi.org/10.17348/era.4.0.51-60.

ALBUQUERQUE, U.P., MEDEIROS, P.M., ALMEIDA, A.L.S., MONTEIRO, J.M., LINS NETO, E.M., MELO, J.G. and SANTOS, J.P., 2007. Medicinal plants of the caatinga (semi-arid) vegetation of NE Brazil: a quantitative approach. Journal of Ethnopharmacology, vol. 114, no. 3, pp. 325-354. http://dx.doi. org/10.1016/j.jep.2007.08.017. PMid:17900836.

ALMEIDA, C.F.C.B.R., AMORIM, E., ALBUQUERQUE, U. and MAIA, M., 2006. Medicinal plants popularly used in the Xingó region: a semi-arid location in Northeastern Brazil. Journal of Ethnobiology and Ethnomedicine, vol. 2, no. 1, pp. 2-15. http:// dx.doi.org/10.1186/1746-4269-2-15. PMid:16393344.

ALVIM, N.A., FERREIRA, M.A., CABRAL, I.E. and ALMEIDA FILHO, A.J., 2006. O uso de plantas medicinais como recurso terapêutico: das influências da formação profissional às implicações éticas e legais de sua aplicabilidade como extensão da prática de cuidar realizada pela enfermeira. Revista Latino-Americana de Enfermagem, vol. 14, no. 3, pp. 316-323. http://dx.doi.org/10.1590/ S0104-11692006000300003. PMid:16926986.

AMOROZO, M.C.M. and GÉLY, A., 1998. Uso de plantas medicinais por caboclos do baixo Amazonas Barcarena, PA, Brasil. Boletim do Museu Paraense Emílio Goeldi, vol. 4, pp. 47-131. 
AMOROZO, M.C.M., 2002. Uso e diversidade de plantas medicinais em Santo Antônio do Leverger, MT, Brasil. Acta Botanica Brasilica, vol. 16, no. 2, pp. 189-203. http://dx.doi. org/10.1590/S0102-33062002000200006.

ANDRADE, A.M., OLIVEIRA, J.P., SANTOS, A.L., FRANCO, C.R., ANTONIOLLI, A.R., ESTEVAM, C.S. and THOMAZZI, S.M., 2010. Preliminary study on the anti-inflammatory and antioxidant activities of the leave extract of Hyptis fruticosa Salzm. ex Benth., Lamiaceae. Revista Brasileira de Farmacognosia, vol. 20, no. 6, pp. 962-968. http://dx.doi.org/10.1590/S0102$695 \times 2010005000034$.

ANDRADE, C.T.S., MARQUES, J.G.W. and ZAPPI, D.C., 2006. Utilização medicinal de cactáceas por sertanejos baianos. Revista Brasileira de Plantas Medicinais, vol. 8, pp. 36-42.

ANDREO, D. and JORGE, N., 2006. Antioxidantes naturais: técnicas de extração. Boletim do Centro de Pesquisa e Processamento de Alimentos, vol. 24, no. 2, pp. 319-326. http://dx.doi.org/10.5380/ cep.v24i2.7489.

AQUINO, A.C., 2012. Enredos de uma travessia: a Ilha do Massangano no Vale do São Francisco. Petrolina: IF Sertão Pernambucano, $220 \mathrm{p}$.

ASTUDILlO-VÁZQUEZ, A., MATA, R. and NAVARRETE, A., 2009. El reino vegetal, fuente de agentes antiespasmódicos gastrointestinales y antidiarreicos. Revista Latinoamericana de Química, vol. 37, pp. 7-43.

BASÍLIO, I.J.L.D., FAGRA, M., ROCHA, E.A., LEAL, C.K.A. and ABRANTES, H.F., 2007. Estudo Farmacobotânico Comparativo das Folhas de Hyptis pectinata (L.) Poit. e Hyptis suaveolens (L.) Poit (Lamiaceae). Latin American Journal of Pharmacy, vol. 25 , pp. $518-525$.

BATISTA SILVA, A., FERREIRA DE ARAÚJO, C.R., PEREIRA DA COSTA, E., CLEMENTINO TAVARES, E. and RIOS MARIZ, S., 2015. Perfil e prevalência de uso de plantas medicinais em uma unidade básica de saúde da família em Campina Grande, Paraíba, Brasil. Revista Brasileira de Ciências Farmacêuticas, vol. 35, pp. 233-238.

BENNETT, B.C. and PRANCE, G.T., 2000. Introduced plants in the indigenous Pharmacopeia of Northern South America. Economic Botany, vol. 54, no. 1, pp. 90-102. http://dx.doi. org/10.1007/BF02866603.

BRASIL, 1988. Constituição da República Federativa do Brasil. Diário Oficial da República Federativa do Brasil, Brasilia, 5 outubro.

BRASIL, 2012. Lei $n^{\circ} 12.651$, de 25 de maio de 2012. Novo Código Florestal. Diário Oficial da República Federativa do Brasil, Brasilia, 28 maio.

CAMPOS, N.J., 2002. Usos e formas de apropriação da terra na Ilha de Santa Catarina. Geosul, vol. 17, pp. 113-136.

CARNEIRO, D.B., BARBOZA, M.S.L. and MENEZES, M.P., 2010. Plantas nativas úteis na Vila dos Pescadores da Reserva Extrativista Marinha Caeté-Taperaçu, Pará: Brasil. Acta Botanica Brasílica, vol. 24, no. 4, pp. 1027-1033. http://dx.doi.org/10.1590/ S0102-33062010000400017.

CARREIRA, L. and ALVIM, N.A.T., 2008. O cuidar ribeirinho: as práticas populares de saúde em famílias da ilha Mutum, Estado do Paraná. Acta Scientiarum. Health Sciences, vol. 24, pp. 791-801. http://dx.doi.org/10.4025/actascihealthsci.v24i0.2548.
CENTENO, L.M.M., 2010. Plantas medicinales españolas Rosmarinus officinalis L. (Lamiaceae) (romero). Studia Botânica, vol. 21, pp. 105-118.

CHEN, Z.S., CHEN, C.X. and KWAN, C.Y., 2000. Leonurine, an alkaloid from Leonurus artemesia, induces contraction in mouse uterine smooth muscle but relaxation in vascular smooth muscle of rat portal vein. Biomedical Research, vol. 11, pp. 209-212.

DIAS, C.T.V. and KIILL, L.H.P., 2007. Ecologia da polinização de Raphiodon echinus (Nees \& Mart.) Schauer (Lamiaceae) em Petrolina - PE, Brasil. Acta Botanica Brasílica, vol. 21, no. 4, pp. 977-982. http://dx.doi.org/10.1590/S0102-33062007000400022.

FABRICANTE, J.R., ZILLER, S.R., ARAÚJO, K.C.T., FURTADO, M.D.D.G. and BASSO, F.D.A., 2015. Non-native and invasive alien plants on fluvial islands in the São Francisco River, northeastern Brazil. Check List, vol. 11, no. 1, pp. 1535. http://dx.doi.org/10.15560/11.1.1535.

FALCÃO, D.Q., FERNANDES, S.B.O. and MENEZES, F.S., 2003. Triterpenos de Hyptis fasciculata Benth. Revista Brasileira de Farmacognosia, vol. 13, pp. 81-83. http://dx.doi.org/10.1590/ S0102-695X2003000300030.

FIRMO, W.D.C.A., MENEZES, V.D.J.M., CASTRO PASSOS, C.E., DIAS, C.N., ALVES, L.P.L., DIAS, I.C.L. and OLEA, R.S.G., 2012. Contexto histórico, uso popular e concepção científica sobre plantas medicinais. Cadernos de Pesquisa, vol. 18, pp. 90-95.

FIUZA, T.S., REZENDE, M.H., SABÓIA-MORAIS, S.M., TRESVENZOL, L.M., FERREIRA, H.D. and PAULA, J.R., 2010. Estudo das folhas e caule de Hyptidendron canum (Pohl ex Benth.) Harley, Lamiaceae. Revista Brasileira de Farmacognosia, vol. 20, no. 2, pp. 192-200. http://dx.doi.org/10.1590/S0102$695 \times 2010000200010$

FORZZA, R.C., LEITMAN, P.M., COSTA, A.F., CARVALHO JÚNIOR, A.A., PEIXOTO, A.L., WALTER, B.M.T. and MARTINELLI, G., 2010 [viewed 12 April 2015]. Lista de espécies da flora do Brasil [online]. Rio de Janeiro: Jardim Botânico do Rio de Janeiro. Available from: http://floradobrasil.jbrj.gov.br/ jabot/floradobrasil/

FREITAS, A.V.L., COELHO, M.D.F.B., MAIA, S.S.S. and AZEVEDO, R.A.B., 2012. Plantas medicinais: um estudo etnobotânico nos quintais do Sítio Cruz, São Miguel, Rio Grande do Norte, Brasil. Revista Brasileira de Biociências, vol. 10, pp. 48.

GALVEZ, J., ZARZUELO, A., CRESPO, M.E., LORENTE, M.D., OCETE, M.A. and JIMÉNEZ, J., 1993. Antidiarrhoeic activity of Euphorbia hirta extract and isolation of an active flavonoid constituent. Planta Medica, vol. 59, no. 4, pp. 333-336. http:// dx.doi.org/10.1055/s-2006-959694. PMid:8372151.

GAZZANEO, L.R., LUCENA, R.F. and ALBUQUERQUE, U.P., 2005. Knowledge and use of medicinal plants by local specialists in a region of Atlantic Forest in the state of Pernambuco (Northeastern Brazil). Journal of Ethnobiology and Ethnomedicine, vol. 1, no. 1, pp. 1-9. http://dx.doi.org/10.1186/1746-4269-1-9. PMid:16270911.

GODINHO, A.L. and GODINHO, H.P., 2003. Breve visão do São Francisco: águas, peixes e pescadores do São Francisco das Minas Gerais. Belo Horizonte: PUC Minas, 182 p.

GRIZ, S.A.S., MATOS-ROCHA, T.J., SANTOS, A.F., COSTA, J.G. and MOUSINHO, K.C., 2017. Medicinal plants profile used by the 3rd District population of Maceió-AL. Brazilian Journal of Biology $=$ Revista Brasileira de Biologia, vol. 77, no. 4, pp. 794802. http://dx.doi.org/10.1590/1519-6984.01116. PMid:28492798. 
GRUBER, C.W. and O'BRIEN, M., 2011. Uterotonic plants and their bioactive constituents. Planta Medica, vol. 77, no. 3, pp. 207220. http://dx.doi.org/10.1055/s-0030-1250317. PMid:20845261.

HÖFLING, J.F., ANIBAL, P.C., OBANDO-PEREDA, G.A., PEIXOTO, I.A.T., FURLETTI, V.F., FOGLIO, M.A. and GONCCALVES, R.B., 2010. Antimicrobial potential of some plant extracts against Candida species. Brazilian Journal of Biology $=$ Revista Brasileira de Biologia, vol. 70, no. 4, pp. 1065-1068. http:// dx.doi.org/10.1590/S1519-69842010000500022. PMid:21180915.

KAMATENESI-MUGISHA, M. and ORYEM-ORIGA, H., 2007. Medicinal plants used to induce labour during childbirth in western Uganda. Journal of Ethnopharmacology, vol. 109, no. 1, pp. 1-9. http://dx.doi.org/10.1016/j.jep.2006.06.011.

LADEJI, O., UDOH, F.V. and OKOYE, Z.S.C., 2005. Activity of aqueous extract of the bark of Vitex doniana on uterine muscle response to drugs. Phytotherapy Research, vol. 19, no. 9, pp. 804-806. http://dx.doi.org/10.1002/ptr.1588. PMid:16220576.

MENEZES, F. and KAPLAN, M.A.C., 2006. In-mixture analysis of triterpenes from Raphiodon echinus. Revista Latinoamericana de Química, vol. 34, pp. 37.

MENEZES, F.S., CARDOSO, G.L.C., PEREIRA, N.A., BORSATTO, A.S. and KAPLAN, M.A.C., 1998. Phytochemical and pharmacological studies on Raphiodon echinus. Fitoterapia, vol. 69 , pp. 459-460.

MISSOURI BOTANICAL GARDEN, 2016 [viewed 12 January 2016]. Plant Classification and Systematics Database [online]. Available from: http://mobot.mobot.org/cgi-bin/search_vast

MOREIRA, R.D.C.T., COSTA, L.D.B., COSTA, R.C.S. and ROCHA, E.A., 2002. Abordagem etnobotânica acerca do uso de plantas medicinais na Vila Cachoeira, Ilhéus, Bahia, Brasil. Latin American Journal of Pharmacy, vol. 21, pp. 205-211.

MORENO, M.D.P.D.N., SIMOTE, S., VIEIRA, P.C., RODRIGUES FILHO, E., SILVA, M.F.D.G.F., FERNANDES, J.B. and CAVALCANTI, S.C., 2005 [viewed 12 April 2015]. Phytochemical evaluation and pharmacological potential of Hyptis fructicosa L. In: Proceedings of the 28 Annual meeting of the Brazilian Chemical Society Chemistry for Sustainable Development and Social Inclusion [online], 2005, Poços de Caldas, MG. São Paulo: Sociedade Brasileira de Química. Available from: https://sec.sbq. org.br/resumos/28RA/T1763-1

OLIVEIRA, A.K.M., OLIVEIRA, N.A., RESENDE, U.M. and MARTINS, P.F.R.B., 2011. Ethnobotany and traditional medicine of the inhabitants of the Pantanal Negro sub-region and the raizeiros of Miranda and Aquidauna, Mato Grosso do Sul, Brazil. Brazilian Journal of Biology $=$ Revista Brasileira de Biologia, vol. 71, no. 1, suppl. 1, pp. 283-289. http://dx.doi.org/10.1590/ S1519-69842011000200007. PMid:21537601.

OLIVEIRA, G.L., OLIVEIRA,A.F.M. and ANDRADE, L.H.C., 2010. Plantas medicinais utilizadas na comunidade urbana de Muribeca, Nordeste do Brasil. Acta Botanica Brasílica, vol. 24, no. 2, pp. 571-577. http://dx.doi.org/10.1590/S0102-33062010000200026.

POTTERAT, O. and HAMBURGER, M., 2007. Morinda citrifolia (Noni) fruit phytochemistry, pharmacology, safety. Planta Medica, vol. 73, no. 3, pp. 191-199. http://dx.doi.org/10.1055/s-2007-967115. PMid: 17286240.

POVH, J.A., SANTOS, F.B. and SILVA, K.R., 2012. Teor de fenóis totais e flavonóides em quatro espécies do gênero Hyptis Jacq. ocorrentes no cerrado. Brazilian Geographical Journal: Geosciences and Humanities Research Medium, vol. 3, no. 2, pp. 3.
RATES, S.M.K., 2001. Plants as sources of drugs. Toxicon, vol. 39, no. 5, pp. 603-613. http://dx.doi.org/10.1016/S00410101(00)00154-9. PMid:11072038.

RODRIGUES, V.E.G. and CARVALHO, D.A., 2001. Levantamento etnobotânico de plantas medicinais no domínio do cerrado na região do Alto Rio Grande - Minas Gerais. Ciência e Agrotecnologia, vol. 25 , no. 1 , pp. 102-123.

ROQUE, A.A., ROCHA, R.M. and LOIOLA, M.I.B., 2010. Uso e diversidade de plantas medicinais da Caatinga na comunidade rural de Laginhas, município de Caicó, Rio Grande do Norte (Nordeste do Brasil). Revista Brasileira de Plantas Medicinais, vol. 12, no. 1, pp. 31-42. http://dx.doi.org/10.1590/S1516-05722010000100006.

SARTORATTO, A., MACHADO, A.L.M., DELARMELINA, C., FIGUEIRA, G.M., DUARTE, M.C.T. and REHDER, V.L.G., 2004. Composition and antimicrobial activity of essential oils from aromatic plants used in Brazil. Brazilian Journal of Microbiology, vol. 35 , no. 4 , pp. $275-280$. http://dx.doi.org/10.1590/S151783822004000300001

SCUR, M.C., PINTO, F.G.S., PANDINI, J.A., COSTA, W.F., LEITE, C.W. and TEMPONI, L.G., 2016. Antimicrobial and antioxidant activity of essential oil and different plant extracts of Psidium cattleianum Sabine. Brazilian Journal of Biology = Revista Brasileira de Biologia, vol. 76, no. 1, pp. 101-108. http:// dx.doi.org/10.1590/1519-6984.13714. PMid:26871744.

SHIH, H.C., HSU, C.S. and YANG, L.L., 2009. In vitro study of the tocolytic effect of oroxylin A from Scutellaria baicalensis root. Journal of Biomedical Science, vol. 16, no. 1, pp. 27. http:// dx.doi.org/10.1186/1423-0127-16-27. PMid:19272127.

SILVA, V.A. and ALBUQUERQUE, U.P., 2004. Técnicas para análise de dados etnobotânicos. In: U.P. ALBUQUERQUE and R.F.P. LUCENA, eds. Métodos e técnicas na pesquisa etnobotânica. Recife: Ed. NUPEEA, p. 63-88.

SOUZA, A.A. and RODRIGUES, S.A., 2012. Atividade antimicrobiana do óleo essencial de Rhaphiodon echinus (Nees \& Mart) Shauer. Biofar, vol. 07, pp. 12-16.

SOUZA, I.L.L., OLIVEIRA, G.A., TRAVASSOS, R., VASCONCELOS, L.H.C., CORREIA, A.C.C., MARTINS, I.R.R., SANTOS JÚNIOR, M.S.M., COSTA, V.C.O., TAVARES, J.F., SILVA, M.S. and SILVA, B.A., 2013. Spasmolytic activity of Hyptis macrostachys Benth. (Lamiaceae). Journal of Medicinal Plants Research, vol. 7, no. 33, pp. 2436-2443.

SOUZA, L.K.H., OLIVEIRA, C.M.A., FERRI, P.H., SANTOS, S.C., OLIVEIRA JÚNIOR, J.G., MIRANDA, A.T.B., LIÃO, L.M. and SILVA, M.R.R., 2002. Antifungal properties of Brazilian Cerrado plants. Brazilian Journal of Microbiology, vol. 33, no. 3 , pp. 247-249. http://dx.doi.org/10.1590/S1517-83822002000300012.

STALCUP, M.M., 2000. Plantas de uso medicinal ou ritual numa feira livre no Rio de Janeiro, Brasil. Rio de Janeiro: Universidade Federal do Rio de Janeiro, 110 p. Dissertação de Mestrado.

THE PLANT LIST [online], 2015 [viewed 1 Aug 2015]. Available from: http://www.theplantlist.org/

TORRES, M.C.M., FLORÊNCIO, L.C.M., SILVEIRA, E.R. and PESSOA, O.D.L., 2009. Chemical Composition of the Essential Oils of Raphiodon echinus (Nees \& Mart.) Schauer. Journal of Essential Oil Bearing Plants, vol. 12, no. 6, pp. 674-677. http:// dx.doi.org/10.1080/0972060X.2009.10643773.

VILJOEN, A., VAN VUUREN, S., ERNST, E., KLEPSER, M., DEMIRCI, B., BAŞER, H. and VAN WYK, B.E., 2003. Osmitopsis asteriscoides (Asteraceae)-the antimicrobial activity 
and essential oil composition of a Cape-Dutch remedy. Journal of Ethnopharmacology, vol. 88, no. 2-3, pp. 137-143. http:// dx.doi.org/10.1016/S0378-8741(03)00191-0. PMid:12963133.

WAGNER, H. and BLADT, S., 1996. Plant drug analysis: a thin layer chromatography atlas. 2. ed. Berlin: Springer Verlag, 384 p. http://dx.doi.org/10.1007/978-3-642-00574-9.

WORLD HEALTH ORGANIZATION - WHO, 2007 [viewed 31 May 2015]. International statistical classification of diseases and related health problems [online]. 10th revision. Geneva. Available from: http://www.who.int/classifications/icd/e

YOUNG, R.C., 2007. Myocytes, myometrium, and uterine contractions. Annals of the New York Academy of Sciences, vol. 1101, no. 1, pp. 72-84. http://dx.doi.org/10.1196/annals.1389.038. PMid: 17442780 .

ZUANAZZI, J.A.S. and MAYORGA, P., 2010. Phytoproducts and economic development. Química Nova, vol. 33, no. 6, pp. 1421-1428. http://dx.doi.org/10.1590/S0100-40422010000600037. 